\title{
Microplastics of different characteristics are incorporated into the larval cases of the freshwater caddisfly Lepidostoma basale
}

\author{
Sonja M. Ehlers ${ }^{1,2, *}$, Werner Manz ${ }^{2}$, Jochen H. E. Koop ${ }^{1}$ \\ ${ }^{1}$ Department of Animal Ecology, Federal Institute of Hydrology, 56068 Koblenz, Germany \\ ${ }^{2}$ Institute for Integrated Natural Sciences, University of Koblenz-Landau, 56070 Koblenz, Germany
}

\begin{abstract}
Plastic pollution is present in aquatic systems worldwide. While numerous studies have investigated microplastic interactions with marine organisms, microplastic effects on freshwater organisms, especially insects, have been rarely studied. Previous studies have mainly focused on dietary uptake of microplastics, but the presence of microplastics in animal constructions is largely unknown. To date, microplastics have only been observed in the tubes of a marine polychaete species. In freshwater systems, common caddisfly (Trichoptera) larvae build cases by using larval silk and mineral grains from benthic sediments, which are known microplastic sinks. Therefore, we examined caddisfly cases for microplastic presence. We collected caddisfly Lepidostoma basale cases in the field, disintegrated them using hydrogen peroxide, and determined microplastic polymer type through micro-Fourier-transform infrared spectroscopy. We found primary and secondary microplastics of different shapes, colors, sizes and chemical compositions (e.g. polypropylene, polyethylene, polyvinyl chloride). Thus, this is the first study to show that microplastics are present in the biological construction of a freshwater organism. Larval stages are usually more vulnerable than adult individuals, and microplastics can transport persistent organic pollutants and emit toxic leachates. In the caddisfly larval case, those substances are in close proximity to the sensitive larval body, which may be harmful for the larva and may eventually impede its development. We discuss the potential of caddisfly larval cases to act as microplastic bioindicators in freshwater habitats.
\end{abstract}

KEY WORDS: Synthetic polymers · Freshwater insects $\cdot$ Trichoptera $\cdot$ Case construction $\cdot$ Stream

\section{INTRODUCTION}

Freshwater ecosystems worldwide, including streams and rivers, are polluted with microplastic debris (Eerkes-Medrano et al. 2015). Such microplastics (plastic particles $<5 \mathrm{~mm}$, Moore 2008) vary in shape (fragment, film, pellet [spherical], foam and fiber; Free et al. 2014), color and chemical composition, and are classified as primary and secondary microplastics (Cole et al. 2011). Primary microplastics such as spherical microbeads are manufactured to be of a very small size. These spheres have multiple

*Corresponding author: sehlers@uni-koblenz.de applications, e.g. as exfoliating agents in cosmetics, and may reach the environment because waste water treatment plants are often inefficient in removing them (Rochman et al. 2015). In contrast, secondary microplastics, such as fragments, films and fibers, are created when larger plastic debris becomes (e.g. mechanically or photolytically) degraded into smaller plastic pieces (Cole et al. 2011). Plastic items from land-based sources can be transported to streams and rivers by wind, rain drainage, waste water and improper disposal of plastic waste (Duis \& Coors 2016). The industrial mass production of plastics

() The authors 2019. Open Access under Creative Commons by Attribution Licence. Use, distribution and reproduction are unrestricted. Authors and original publication must be credited. 
started in the 1940s (Cole et al. 2011), and microplastics were reported in the oceans as early as the 1970s (Carpenter et al. 1972, Carpenter \& Smith 1972). Since then, numerous studies have examined the impact of microplastics on marine organisms (Erren et al. 2013, Wright et al. 2013, Egbeocha et al. 2018), including vertebrates (Germanov et al. 2018) and invertebrates (Cole et al. 2013, Kaposi et al. 2014). Rivers are important sources of marine microplastics, as they transport plastic debris from inland waters to the ocean (Lebreton et al. 2017). Despite this important pathway, freshwater microplastics have been considerably less studied than microplastics in the marine environment (Eerkes-Medrano et al. 2015). Regarding the interactions of microplastics with freshwater organisms, recent studies have mainly focused on microplastic ingestion by vertebrates, e.g. fish (Horton et al. 2018, McNeish et al. 2018), and invertebrates, such as mollusks (Su et al. 2018) and crustaceans (Weber et al. 2018), and on the resulting physiological effects (Ding et al. 2018, RedondoHasselerharm et al. 2018). Despite the great abundance and ecological importance of aquatic insects (Suter \& Cormier 2015), microplastic studies on those organisms are just emerging and largely focus on microplastic dietary uptake (Kim et al. 2018, Nel et al. 2018, Windsor et al. 2019).

Besides microplastic ingestion, microplastics may be incorporated into the structures built by animals. For instance, the marine tube-building polychaete Gunnarea gaimardi (Quatrefages, 1848) incorporates microplastics into its housing (Nel \& Froneman 2018), and thereby fixes microplastic particles in a biological construction. Similar biological structures in freshwater habitats are larval cases that several epibenthic caddisfly (Trichoptera) species build. It has recently been suggested that microplastics may be fixed in caddisfly larval cases, but no analysis such as microFourier-transform infrared ( $\mu$ FTIR) spectroscopy has been performed to verify that the particles which were observed in caddisfly larval cases were microplastics and that they were not, for example, parts of ceramics or cardboard (Tibbetts et al. 2018). Hence, to investigate if freshwater microplastics may be incorporated into caddisfly larval cases, we analyzed whether microplastics are present in those cases and which characteristics (shape, polymer type, color, size) such microplastics possess.

After hatching from the eggs, the larvae of many caddisfly species start building cases to protect themselves from predators (Boyero et al. 2006) and from environmental influences (Zamora Muñoz \& Svensson 1996). As the larvae grow, new material is added to the anterior end of the case and secured with silk filaments produced by the larvae (Stewart \& Wang 2010). For case building, caddisfly larvae actively collect different biotic (e.g. leaves; Sheath et al. 1995, Moretti et al. 2009) and abiotic (e.g. sediment grains; Gaino et al. 2002, Okano et al. 2012) materials, and some species use both material types (Hansell 1972). Different caddisfly species differ in their preferences for certain case-building materials (Hanna 1961).

Recently, a few potential sentinel species for microplastic pollution in freshwater ecosystems have been suggested, including tadpoles (Hu et al. 2018) and Asian clams (Su et al. 2018), but none has been established so far. Therefore, we discuss the potential role of caddisfly larval cases as bioindicators for freshwater microplastics which might facilitate microplastic assessment in streams and rivers.

Given that a marine polychaete species incorporates microplastics into its tube (Nel \& Froneman 2018), and freshwater sediments are a sink for microplastics (Castañeda et al. 2014), we hypothesized that microplastics would be fixed in the larval cases of the caddisfly Lepidostoma basale, which uses sediment grains for case building (Skuja 2010). We tested our hypothesis through an observational field study.

\section{MATERIALS AND METHODS}

\subsection{Study site}

We conducted our study in the Saynbach stream $\left(50.438399^{\circ} \mathrm{N}, 7.5732430^{\circ} \mathrm{E}\right)$, located in the Schlosspark Sayn, a public park in the town of Bendorf (Rhineland-Palatinate, Germany). This stream originates in Himburg (Rhineland-Palatinate) and flows directly into the Rhine River. The stream has a length of $43.7 \mathrm{~km}$, a width of 3 to $4 \mathrm{~m}$, a depth of 6 to $40 \mathrm{~cm}$ and a catchment area of $219 \mathrm{~km}^{2}$ (Beckmann et al. 2005). Downstream of our study site in the Schlosspark Sayn, the Saynbach passes the Bendorf wastewater treatment plant before leading into the Rhine.

The abiotic conditions of the Saynbach are regularly measured by the Rhineland-Palatinate State Office for the Environment (Landesamt für Umwelt) at a nearby location $\left(50.429^{\circ} \mathrm{N}, 7.565^{\circ} \mathrm{E}\right)$. On 10 April 2018 at 15:40 h Central European Summer Time (1 d before we collected caddisfly larvae; see Section 2.2), water temperature was $13.6^{\circ} \mathrm{C}$, turbidity was 8 formazin nephelometric units, $\mathrm{pH}$ was 8.4 , conductivity (at $20^{\circ} \mathrm{C}$ ) was $264 \mu \mathrm{S} \mathrm{cm}^{-1}$, and oxygen concentration was $10.9 \mathrm{mg} \mathrm{l}^{-1}$. The Saynbach sediment at the study site consisted of sand and fine gravel. 


\subsection{Caddisfly larvae collection and identification}

On 11 April 2018, we manually collected casebearing caddisfly larvae in individual glass vials (Wheaton, DWK Life Sciences) that contained $70 \%$ ethanol. All larvae were collected at random and had intact cases. To avoid airborne microplastic contamination of the larvae, we wore cotton clothes. Furthermore, the vials used for sampling were previously rinsed with ultrapure water.

At the lab, we identified 29 of the 30 caddisfly larvae as Lepidostoma basale (Kolenati, 1848) under a binocular microscope according to morphological species keys (Wallace et al. 1990, Waringer \& Graf 2011). This caddisfly (former synonym: Lasiocephala basalis) occurs in streams and rivers across Europe (Moretti et al. 1981, Beisel et al. 1998, Hoffmann 2000, Chadd \& Extence 2004, Bonada et al. 2008, Skuja 2010, Verdonschot et al. 2010). It lives on woody debris, shows facultative xylophagy (Hoffmann \& Hering 2000) and feeds on biofilms (Schulte et al. 2003). $L$. basale larvae can feed on invertebrates (Schulte et al. 2003) and leaf litter (Hoffmann 2000). Annual L. basale development proceeds through 5 larval stages and 1 pupal stage (Verdonschot et al. 2010). In all larval stages (i.e. instars), L. basale constructs mineral cases (Skuja 2010); in the fifth-instar larva, the case has a maximum length of ca. $1.5 \mathrm{~cm}$ (Hoffmann 2000). In L. basale, individuals of different larval stages (and thereby of different sizes) can be found simultaneously at the same location (Verdonschot et al. 2010).

We identified the remaining caddisfly larva as either Sericostoma personatum (Spence in Kirby \& Spence, 1826) or Sericostoma flavicorne Schneider, 1845, whose taxonomic differentiation is not fully understood (Waringer 1987, Malicky 2005), but has recently been clarified to some extent by genetical analyses (Weigand et al. 2017). S. personatum larvae are detritivore-shredders that feed on leaves (Friberg \& Jacobsen 1999). As we only found 1 individual of this species, we present information on microplastics in its larval case as an additional observation but focus on the larval cases of $L$. basale.

\subsection{Preparation of caddisfly larval cases}

We measured caddisfly larval case length along the convex case side using a digital microscope (VHX2000, Keyence). We then removed the larvae from their cases using metal forceps. To remove any particles that adhered to the case surface but were not fixed in the case matrix, we carefully rinsed all cases in ultrapure water and put them into individual glass Petri dishes. Next, we dried the cases at $40^{\circ} \mathrm{C}$ for $4 \mathrm{~h}$ in a drying cabinet and immediately measured their dry weight using an analytical balance (XS205 DualRange Analytical Balance, Mettler Toledo).

To prevent microplastic contamination, we thoroughly cleaned all lab surfaces and glassware using $70 \%$ ethanol and ultrapure water before starting labwork. Furthermore, to prevent microplastic crosscontamination between the caddisfly larval cases, we carefully rinsed our forceps between samples. Finally, to prevent airborne microplastic contamination, we immediately covered all Petri dishes containing caddisfly larval cases with aluminum foil.

\subsection{Caddisfly larval case oxidation and density separation}

For case disintegration, we transferred all rinsed caddisfly larval cases into individual glass beakers in which we submerged each case in $20 \mathrm{ml}$ of a hydrogen peroxide solution (34.5-36.5\% $\mathrm{H}_{2} \mathrm{O}_{2}$ ) to disintegrate them and remove any organic substances present. All beakers were then covered with parafilm and left on a shaking table at $150 \mathrm{rpm}$ for $7 \mathrm{~d}$ until the cases were completely disintegrated. Nuelle et al. (2014) previously showed that such $\mathrm{H}_{2} \mathrm{O}_{2}$ solutions can successfully reduce organics in sediment sample matrices similar to caddisfly case matrices. Occasionally, stirring the samples with a glass rod can help in case disintegration. We ran blanks parallel to the case disintegration and scanned them for microplastics, but did not detect any parafilm or microplastic particles in the blanks. However, we found natural fibers in the blanks which we identified using $\mu$ FTIR.

After case disintegration, we separated the resulting minerals from the microplastics through density separation. To do so, we transferred each sample to a glass separation funnel to which we added potassium formate $(99 \%)$ until the solution was saturated at about $1.6 \mathrm{~g} \mathrm{ml}^{-1}$, a similar approach to that used to separate microplastics from sediment grains in sediment samples (Zhang et al. 2016). Again, we ran blanks with the density separation to exclude microplastic contamination from, for example, the lid of the container in which the potassium formate was stored. After approximately $3 \mathrm{~h}$, the mineral grains had settled to the bottom of the funnel. We then drained the grains and filtered the supernatant onto aluminum oxide filters (Anodisc filter; pore size $0.2 \mu \mathrm{m}_{\text {; diame- }}$ ter $47 \mathrm{~mm}$, Whatman) using a pressure filtration unit (model 16249, Sartorius). We chose these filters to en- 
able $\mu$ FTIR measurements in transmission mode during further microplastic analyses (Löder et al. 2015).

We placed the filters in small aluminum bowls, covered them with aluminum foil and placed them in a drying cabinet $\left(50^{\circ} \mathrm{C}\right)$ for $2 \mathrm{~d}$. We then visually inspected each filter for microplastics using a digital microscope (VHX-2000, Keyence) and identified all microplastics by their unnatural color and shape (Hidalgo-Ruz et al. 2012). The shapes for microplastic particle classification were sphere, film (thin and small layer), fragment (part of a larger plastic item) and fiber (Su et al. 2016, 2018). We recorded the occurrence of microplastics and measured their dimensions (maximum length of fragments, films and fibers, and the diameter of the spheres).

\section{5. $\mu$ FTIR analyses of microplastics found in caddisfly larval cases}

We manually analyzed all microplastics found in the L. basale cases using a Hyperion 2000 FTIR microscope equipped with a mercury-cadmium telluride detector (Bruker) in a wavenumber range of 4000$600 \mathrm{~cm}^{-1}$ with $32 \mathrm{co}$-added scans and a spectral resolution of $4 \mathrm{~cm}^{-1}$. The software used was OPUS 7.5, and we compared the obtained spectra with the Bruker database. As in previous studies, only particles with a hit quality of over 700 were considered as microplastics (Bergmann et al. 2017). We analyzed the microplastics using attenuated total reflectance ( $\mu$ ATR) with a germanium crystal and an ATR 20× objective. For some particles that were difficult to analyze, we used $\mu$ ATR and transmission mode (with a $15 \times$ infrared objective). For measurements in transmission mode, the blank aluminum oxide filter was used for background measurements. Measuring the blank filter material as a background in transmission measurements is a common procedure for $\mu$ FTIR measurements in microplastics research (Löder et al. 2015).

\subsection{Sediment and water samples}

We manually collected 5 sediment samples within meters of the caddisfly collection site using yellow containers. As in previous studies, sediment was sampled to a depth of ca. $10 \mathrm{~cm}$ and as little surface water as possible was collected along with the sediment (Tibbetts et al. 2018). At the laboratory, we freezedried the wet sediment samples, a common procedure in microplastic research (Matsuguma et al. 2017), and took subsamples with a dry weight of $15.64 \pm 0.17 \mathrm{~g}$ (mean $\pm \mathrm{SE}, \mathrm{n}=5$ sediment subsamples, range: $15.16-$ $16.15 \mathrm{~g})$. We then transferred each subsample to an individual glass beaker which we covered with aluminum foil to avoid airborne microplastic contamination of our samples. To facilitate the sediment analysis, we digested organic matter using $20 \mathrm{ml} 10 \mathrm{M}$ $\mathrm{KOH}$ and $20 \mathrm{ml} \mathrm{H}_{2} \mathrm{O}_{2}(34.5-36.5 \%)$ on a shaking table. The beakers were covered with parafilm, and controls were run in parallel to the digestion. $\mathrm{KOH}$ was then neutralized with formic acid, as aluminum oxide membrane filters are sensitive to alkaline conditions. Afterwards, sediment grains were separated from microplastics using density separation with potassium formate. Again, blanks were run during digestion and density separation. Moreover, we took 4 water samples (again using yellow containers) with a volume of $467.5 \pm 11.09 \mathrm{ml}$ (mean $\pm \mathrm{SE}, \mathrm{n}=4$ water samples, range: $450-500 \mathrm{ml}$ ) each close to the caddisfly collection site. In the laboratory, the water samples were transferred to glass beakers and freeze-dried. Afterwards, we digested organic materials inside the suspended sediment fraction using $10 \mathrm{ml} 10 \mathrm{M} \mathrm{KOH}$ and $20 \mathrm{ml} \mathrm{H}_{2} \mathrm{O}_{2}$ (34.5-36.5\%), neutralized the $\mathrm{KOH}$ with formic acid and performed density separation as well as filtration onto aluminum oxide membrane filters. Again, no microplastic particles were found in the blanks. After transferring the samples onto aluminum oxide membrane filters, sediment and water microplastic loads were analyzed under the digital microscope as well as under the $\mu$ FTIR. Again, $\mu$ FTIR measurements were conducted using $\mu \mathrm{ATR}$, and only particles with a hit quality greater than 700 were considered as microplastics. Furthermore, special care was taken to avoid contact between the germanium crystal and sand grains to prevent any damage to the crystal. No yellow particles that might have come from the containers for sediment and water sampling were found inside the samples.

\section{RESULTS}

\subsection{Microplastics in caddisfly cases}

In Lepidostoma basale, the average larval case length was $0.85 \pm 0.04 \mathrm{~cm}$ (mean $\pm \mathrm{SE}, \mathrm{n}=29$ cases, range: $0.65-1.40 \mathrm{~cm}$ ) and average larval case dry weight was $6.40 \pm 0.63 \mathrm{mg}$ (mean $\pm \mathrm{SE}$ ). The Sericostoma personatum/flavicorne larval case had a length of $1.26 \mathrm{~cm}$ and a dry weight of $34.07 \mathrm{mg}$.

Out of the 29 L. basale larvae, 17 individuals (59\%) had microplastics of different shapes fixed into their cases (Fig. 1). The average microplastic load per indi- 


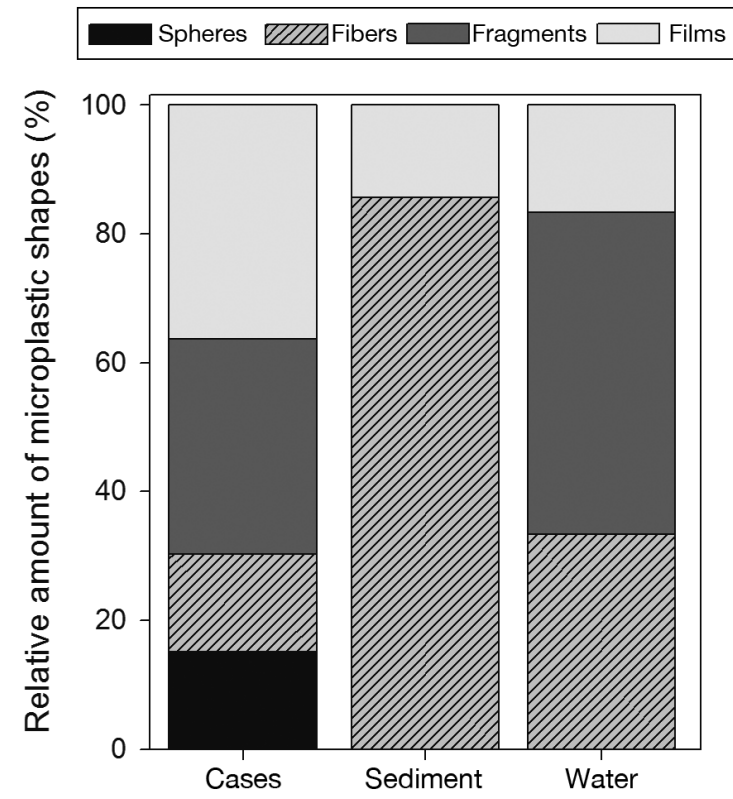

Fig. 1. Relative amount (in \%) of different microplastic shapes (sphere, fiber, fragment, film) in Lepidostoma basale cases $(\mathrm{n}=17)$, sediment $(\mathrm{n}=5$ samples) and water $(\mathrm{n}=4$ samples $)$

vidual was $1.14 \pm 0.28$ microplastics per caddisfly larval case (mean $\pm \mathrm{SE}, \mathrm{n}=29$ caddisfly larval cases, range: $0-6$ microplastics per individual case). The average microplastic load was $0.36 \pm 0.09$ microplastics $\mathrm{mg}^{-1}$ case dry weight (mean $\pm \mathrm{SE}, \mathrm{n}=17$ caddisfly larval cases, range: $0.07-1.44$ microplastics $\mathrm{mg}^{-1}$ case dry weight). In the $S$. personatum/flavicorne case we detected 2 polyamide (PA) microplastics.

$\mu F T I R$ spectroscopy revealed that microplastics in the $L$. basale cases consisted of the polymers polypropylene (PP), PA, acrylonitrile-butadiene-styrene $(\mathrm{ABS})$, a blend of PA and ABS, polyacrylamide (PAM), thermoplastic polyurethane (TPU), vinyl ester resin (VE), polyvinyl chloride (PVC), polyethylene (PE) and polyester (Fig. 2). The microplastic particles incorporated into the caddisfly cases also showed a wide spectrum of colors (Fig. 3).

Furthermore, we found rayon, a cellulose-based, semi-synthetic material, in the cases. It is debated as to whether rayon should be counted as microplastic, considering its highly processed structure and potential environmental effects (Song et al. 2015). In our study, rayon was rare, so we did not consider it as a microplastic.

The microplastic fragments had an average length of $236.09 \pm 33.44 \mu \mathrm{m}$ (mean $\pm \mathrm{SE}, \mathrm{n}=11$ microplastic fragments, range: $40-375 \mu \mathrm{m})$. The films had an average length of $98.92 \pm 18.57 \mu \mathrm{m}(\mathrm{n}=12$ films, range: $27-191 \mu \mathrm{m})$. The plastic spheres had an average diameter of $91.20 \pm 25.88 \mu \mathrm{m}(\mathrm{n}=5$ spheres,

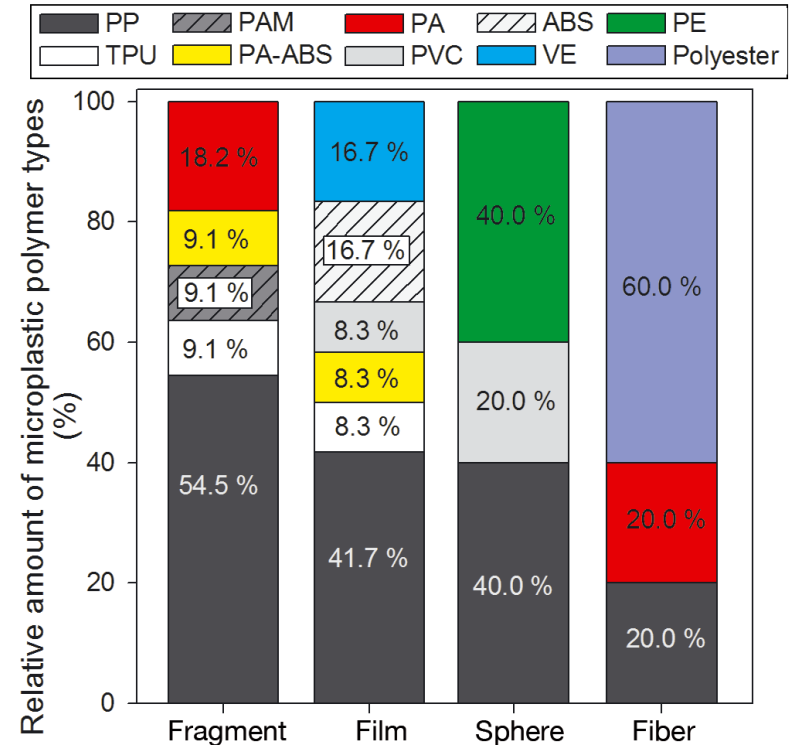

Fig. 2. Relative amount (\%) of microplastic polymer types (PP: polypropylene; TPU: thermoplastic polyurethane; PAM: polyacrylamide; PA: polyamide; ABS: acrylonitrile-butadiene-styrene; PVC: polyvinyl chloride; VE: vinyl ester resin; PE: polyethylene) of microplastic fragments, films, spheres and fibers found in Lepidostoma basale caddisfly cases
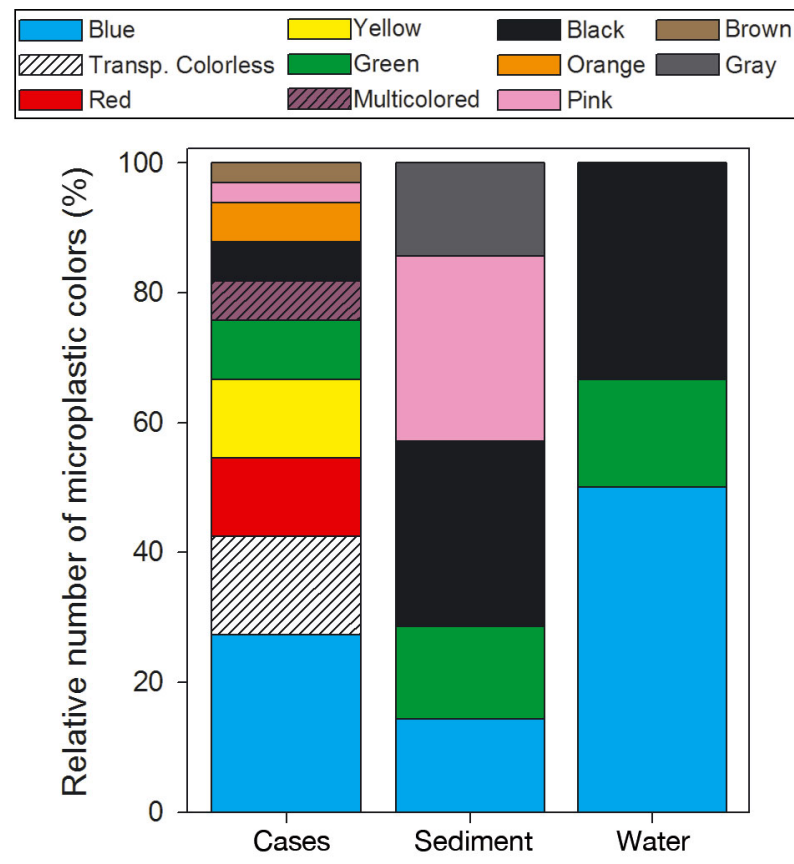

Fig. 3. Relative number (in \%) of differently colored microplastics found in Lepidostoma basale cases ( $\mathrm{n}=17$ ), sediment ( $\mathrm{n}=5$ samples) and water ( $\mathrm{n}=4$ samples). Transp.: transparent

range: $29-163 \mu \mathrm{m}$ ) and the microplastic fibers had an average length of $1872.40 \pm 1434.03 \mu \mathrm{m}(\mathrm{n}=5$ fibers, range: $295-7601 \mu \mathrm{m})$. 


\subsection{Analyses of sediment and water samples}

The sediment subsamples had a microplastic load of $0.09 \pm 0.05$ microplastics $g^{-1}$ (mean $\pm \mathrm{SE}, \mathrm{n}=5$ sediment subsamples, range: $0-0.255$ microplastics $\mathrm{g}^{-1}$ ). Most of the sediment microplastics were fibers (Fig. 1). According to $\mu$ FTIR measurements, sediment microplastics consisted of polyethylene, acryl and polyester. The 4 water samples contained a microplastic load of $0.003 \pm 0.001$ microplastics $\mathrm{ml}^{-1}(\mathrm{n}=4$ water samples, range: 0.002-0.007 microplastics $\mathrm{ml}^{-1}$ ). Among these microplastics, we found urea formaldehyde resin and silicone rubber.

\section{DISCUSSION}

In our study, we found primary (spheres) as well as secondary (fibers, films, fragments) microplastics incorporated into the larval cases of Lepidostoma basale. The spheres accounted for $15.2 \%$ of the microplastics found and resemble those that are commonly used in cosmetics (Tanaka \& Takada 2016). In contrast, secondary microplastics, such as the fragments, films and fibers in the caddisfly cases, are created when larger plastic debris becomes degraded into smaller plastic pieces (Cole et al. 2011). The L. basale individuals that we analyzed had primary and secondary microplastics of different shapes, polymer types, sizes and colors fixed in their cases (see Figs. A1 \& A2 in the Appendix). Those results were verified by $\mu$ FTIR analysis, a crucial step in microplastic analysis, as up to $70 \%$ of particles found in the environment can visually be misidentified as microplastics (HidalgoRuz et al. 2012). Hence, we showed that freshwater microplastics of different characteristics are incorporated into $L$. basale larval cases.

As caddisfly larval cases contain material available in the water body the larva inhabits, the microplastics found inside the $L$. basale case matrix in this study must be a subset of the microplastics suspended in the Saynbach. Thus, caddisfly case analysis may provide information on the diversity of microplastics present in a caddisfly's habitat. Inside the caddisfly larval case matrix, the microplastic particles are fixed with silk, and mineral cases show a particularly high stability (Otto \& Svensson 1980). As L. basale mineral cases contain a low fraction of organic material and lower amounts of sand grains than sediment samples, a filter resulting from the caddisfly case processing is easier to visually analyze than a filter with a sediment microplastic fraction. The latter is often characterized by not fully digested organic residues and small sand grains which could not fully be removed by density separation (Mathalon \& Hill 2014). For instance, we found a small yellow PP sphere with a diameter of $43 \mu \mathrm{m}$ and a small orange PP film with a length of $73 \mu \mathrm{m}$ in the caddisfly cases (see Fig. A1F) which might have been easily overlooked in visual sediment analysis due to their similarity to sediment sand grains.

The disintegration of the cases enabled us to analyze all microplastics present in the caddisfly cases. Some microplastics which might have been part of the inner case wall or were previously covered by sediment grains inside the case matrix (see Fig. A3 in the Appendix) would have been overlooked without dissolving the cases. Also, the usage of the digital microscope allowed us to record microplastic particles which are normally not visible to the naked eye. Nuelle et al. (2014) showed that a 7 d long treatment with $35 \% \mathrm{H}_{2} \mathrm{O}_{2}$ successfully digests organic materials but might lead to color and size loss in some polymer types. The strong colors of the microplastics that we found in the caddisfly cases (see Fig. A1) suggest that there was no bleaching of microplastics due to the usage of $\mathrm{H}_{2} \mathrm{O}_{2}$, perhaps aided by microplastic protection inside the caddisfly case matrix during digestion.

The cases exhibited microplastics with a range of chemical compositions (PE, PP, TPU, PA, PAM, VE, PVC, ABS, polyester). Low-density microplastics such as ABS (density 1.02-1.07 $\mathrm{g} \mathrm{cm}^{-3}$ ) can float in the water column (McCormick et al. 2016), whereas highdensity microplastics such as PVC (density ca. 1.20$1.45 \mathrm{~g} \mathrm{~cm}^{-3}$, Avio et al. 2017) are denser than freshwater and accumulate in sediments (Wright et al. 2013). In the caddisfly cases, we found not only plastics with high densities such as PVC, but also microplastics with low density such as ABS, PE (density 0.93-0.98 $\mathrm{g} \mathrm{cm}^{-3}$, Avio et al. 2017) and PP (density 0.89-0.91 $\mathrm{g} \mathrm{cm}^{-3}$, Avio et al. 2017). Hence, it is likely that factors such as turbulence (McCormick et al. 2016) or an increase in microplastic density caused by a biofilm cover (Lagarde et al. 2016, Rummel et al. 2017) led to low-density microplastic sedimentation and made it available for caddisfly larvae. Similarly, we found PE in the sediment samples. The fact that the sediment samples showed higher microplastic loads than the water samples corroborates that the microplastics in the sampled caddisfly cases stem from the stream sediments. However, as water flows through the caddisfly case (Williams et al. 1987), it cannot be ruled out that some microplastics inside the caddisfly case may come from the water column. The fact that the microplastic load in the caddisfly cases was higher than in the sediment and water samples 
indicates that caddisfly cases may act as microplastic sinks in freshwater habitats.

The $\mu$ FTIR analysis revealed that a high proportion of the microplastics were made of PP and that many spheres consisted of $\mathrm{PE}$, which are the most commonly used plastics (Zhang et al. 2016). They serve as material for different single-use items such as plastic bags, bottle caps and drinking straws which are used in high quantities and regularly accumulate in the environment after disposal (Andrady 2011).

Our results suggest that the plastic types which are most frequently used, and are therefore probably the most prevalent in the environment, are incorporated into caddisfly cases. This finding implies that caddisfly cases may potentially be used as quantitative bioindicators for microplastics. However, future studies should test the potential of caddisfly larval cases as quantitative freshwater microplastic bioindicators by comparing microplastic loads in caddisfly cases from streams differing in plastic pollution. Furthermore, future studies could examine if microplastic loads in caddisfly larval cases may change according to seasonal flow rates. For instance, amounts of microplastics ingested by chironomid larvae show the same seasonal fluctuations as sediment microplastic loads (Nel et al. 2018).

In our study, the only polymers which we found in the caddisfly cases as well as in the sediment samples were $\mathrm{PE}$ and polyester, suggesting that $L$. basale cases may have the potential to act as qualitative microplastic bioindicators. The reason why we did not find more similarities between microplastics in caddisfly cases and in the sediment and water samples may be the limited number of specimens from just 1 species which was analyzed in our study. Different caddisfly species use different case building materials and may therefore more likely represent the variety of microplastics present in their habitats when analyzed together.

In our study, all sediment and water microplastic shapes were reflected in the $L$. basale cases. However, microplastic spheres were only found in the caddisfly cases and not in the sediment and water samples. An explanation for this may be that spheres were present in the sediment and water samples, but could not be detected as they were covered by residues which are characteristic for filters from sediment and water samples. In the caddisfly cases, the spheres were as small as $29 \mu \mathrm{m}$ and were yellow or transparent and colorless, which may further restrict the chances of finding them on filters covered by residues. Therefore, analyzing caddisfly cases might help identify microplastics which are present in an aquatic habitat but cannot easily be detected in sediment and water samples.

The disintegration of caddisfly cases used in our study does not require extensive amounts of chemicals and sieving and is therefore less costly and less time consuming than sediment analyses (Klein et al. 2015). Hence, screening of caddisfly cases might be a cost- and time-effective first step in assessing if microplastics of different characteristics are present in a freshwater habitat.

As the case-building larvae of some caddisfly species occur in brackish and marine environments (Haage 1968, Mouro et al. 2016), future studies should investigate if their cases contain microplastics and may thereby provide information on microplastic characteristics in marine habitats. The fact that a marine polychaete species (Nel \& Froneman 2018) and freshwater caddisfly larvae incorporate microplastics inside their tube-like structures may indicate a general microplastic fixation process present across different ecosystems. Other freshwater organisms such as dipterans also construct tube-like structures (Brennan \& McLachlan 1979), and in terrestrial systems, termites use soil particles for building mounds which have sizes similar to the microplastics found in our study (Jouquet et al. 2002). Furthermore, bagworm moth larvae construct self-enclosing bags using organic and inorganic materials (Rhainds et al. 2009). These biological constructions could be analyzed for microplastics in future studies and potentially provide information on ecosystem-wide processes of microplastic fixation.

Future research should also examine the effects of microplastics in insect constructions as indirect stressors. As plastics often contain harmful additives (Hermabessiere et al. 2017), might increase the risk of cancer (Erren et al. 2013) and may transport pathogenic bacteria (McCormick et al. 2014), microplastics in caddisfly cases may affect caddisfly larvae. For instance, plastic leachates harm brown mussel larvae (Gandara e Silva et al. 2016), and PVC (which was observed in the caddisfly cases) leads to increased mortality in barnacle larvae (Li et al. 2016). We conclude that caddisfly larval cases may have the potential to be used as freshwater microplastic bioindicators. However, future studies should analyze microplastic contents of cases from different caddisfly species and from habitats differing in plastic pollution levels.

Acknowledgements. We thank Georg Reifferscheid for providing the pressure filtration unit, and Friederike Stock and Niklas Arendt (Department of Biochemistry and Ecotoxicology, Federal Institute of Hydrology, BfG) for lab assistance, Barbara Anderer and Esther Behring (Department of Animal 
Ecology, BfG) for caddisfly identification, Esther Behring for field assistance and Bettina Salinus (Department of Animal Ecology, BfG) for lab assistance. We also thank 4 anonymous reviewers for their constructive comments on the original manuscript. This research did not receive any specific grant from funding agencies in the public, commercial or not-forprofit sectors.

\section{LITERATURE CITED}

Andrady AL (2011) Microplastics in the marine environment. Mar Pollut Bull 62:1596-1605

Avio CG, Gorbi S, Regoli F (2017) Plastics and microplastics in the oceans: from emerging pollutants to emerged threat. Mar Environ Res 128:2-11

Beckmann MC, Schöll F, Matthaei CD (2005) Effects of increased flow in the main stem of the River Rhine on the invertebrate communities of its tributaries. Freshw Biol 50:10-26

Beisel JN, Usseglio-Polatera P, Thomas S, Moreteau JC (1998) Stream community structure in relation to spatial variation: the influence of mesohabitat characteristics. Hydrobiologia 389:73-88

* Bergmann M, Wirzberger V, Krumpen T, Lorenz C, Primpke S, Tekman MB, Gerdts G (2017) High quantities of microplastic in Arctic deep-sea sediments from the HAUSGARTEN Observatory. Environ Sci Technol 51: 11000-11010

Bonada N, Zamora-Muñoz C, El Alami M, Múrria C, Prat N (2008) New records of Trichoptera in reference Mediterranean-climate rivers of the Iberian peninsula and North of Africa: taxonomical, faunistical and ecological aspects. Graellsia 64:189-208

Boyero L, Rincón PA, Bosch J (2006) Case selection by a limnephilid caddisfly [Potamophylax latipennis (Curtis)] in response to different predators. Behav Ecol Sociobiol 59: 364-372

Brennan A, McLachlan AJ (1979) Tubes and tube-building in a lotic Chironomid (Diptera) community. Hydrobiologia 67:173-178

* Carpenter EJ, Smith KL Jr (1972) Plastics on the Sargasso Sea surface. Science 175:1240-1241

Carpenter EJ, Anderson SJ, Harvey GR, Miklas HP, Peck BB (1972) Polystyrene spherules in coastal waters. Science 178:749-750

* Castañeda RA, Avlijas S, Simard MA, Ricciardi A (2014) Microplastic pollution in St. Lawrence river sediments. Can J Fish Aquat Sci 71:1767-1771

Chadd R, Extence C (2004) The conservation of freshwater macroinvertebrate populations: a community-based classification scheme. Aquat Conserv 14:597-624

* Cole M, Lindeque P, Halsband C, Galloway TS (2011) Microplastics as contaminants in the marine environment: a review. Mar Pollut Bull 62:2588-2597

* Cole M, Lindeque P, Fileman E, Halsband C, Goodyear R, Moger J, Galloway TS (2013) Microplastic ingestion by zooplankton. Environ Sci Technol 47:6646-6655

№ng J, Zhang S, Razanajatovo RM, Zou H, Zhu W (2018) Accumulation, tissue distribution, and biochemical effects of polystyrene microplastics in the freshwater fish red tilapia (Oreochromis niloticus). Environ Pollut 238:1-9

* Duis K, Coors A (2016) Microplastics in the aquatic and terrestrial environment: sources (with a specific focus on personal care products), fate and effects. Environ Sci Eur 28:2
Eerkes-Medrano D, Thompson RC, Aldridge DC (2015) Microplastics in freshwater systems: a review of the emerging threats, identification of knowledge gaps and prioritisation of research needs. Water Res 75:63-82

Egbeocha CO, Malek S, Emenike CU, Milow P (2018) Feasting on microplastics: ingestion by and effects on marine organisms. Aquat Biol 27:93-106

Erren T, Zeuß D, Steffany F, Meyer-Rochow VB (2013) Oceans of plastics: possible risks of cancer in marine wildlife and humans. In: Allodi S, Nazari EM (eds) Exploring themes on aquatic toxicology. Research Signpost, Trivandrum, p 51-74

Free CM, Jensen OP, Mason SA, Eriksen M, Williamson NJ, Boldgiv B (2014) High-levels of microplastic pollution in a large, remote, mountain lake. Mar Pollut Bull 85:156-163

Friberg N, Jacobsen D (1999) Variation in growth of the detritivore-shredder Sericostoma personatum (Trichoptera). Freshw Biol 42:625-635

*Gaino E, Cianficconi F, Rebora M, Todini B (2002) Casebuilding of some Trichoptera larvae in experimental conditions: selectivity for calcareous and siliceous grains. Ital J Zool 69:141-145

Gandara e Silva PP, Nobre CR, Resaffe P, Pereira CDS, Gusmão F (2016) Leachate from microplastics impairs larval development in brown mussels. Water Res 106:364-370

*Germanov ES, Marshall AD, Bejder L, Fossi MC, Loneragan NR (2018) Microplastics: no small problem for filter-feeding megafauna. Trends Ecol Evol 33:227-232

Haage P (1968) On the salinity tolerance of eggs and young larvae of Phryganea grandis Linné (Trichoptera). Hydrobiologia 32:257-270

Hanna HM (1961) Selection of materials for case-building by larvae of caddis flies (Trichoptera). Proc R Entomol Soc Lond Ser A Gen Entomol 36:37-47

Hansell MH (1972) Case building behaviour of the caddis fly larva, Lepidostoma hirtum. J Zool 167:179-192

* Hermabessiere L, Dehaut A, Paul-Pont I, Lacroix C, Jezequel R, Soudant P, Duflos G (2017) Occurrence and effects of plastic additives on marine environments and organisms: a review. Chemosphere 182:781-793

* Hidalgo-Ruz V, Gutow L, Thompson RC, Thiel M (2012) Microplastics in the marine environment: a review of the methods used for identification and quantification. Environ Sci Technol 46:3060-3075

*Hoffmann A (2000) The association of the stream caddisfly Lasiocephala basalis (KOL.) (Trichoptera: Lepidostomatidae) with wood. Int Rev Hydrobiol 85:79-93

* Hoffmann A, Hering D (2000) Wood-associated macroinvertebrate fauna in central European streams. Int Rev Hydrobiol 85:25-48

* Horton AA, Jürgens MD, Lahive E, van Bodegom PM, Vijver MG (2018) The influence of exposure and physiology on microplastic ingestion by the freshwater fish Rutilus rutilus (roach) in the River Thames, UK. Environ Pollut 236:188-194

* Hu L, Chernick M, Hinton DE, Shi H (2018) Microplastics in small waterbodies and tadpoles from Yangtze River Delta, China. Environ Sci Technol 52:8885-8893

Kouquet P, Lepage M, Velde B (2002) Termite soil preferences and particle selections: strategies related to ecological requirements. Insectes Soc 49:1-7

Kaposi KL, Mos B, Kelaher BP, Dworjanyn SA (2014) Ingestion of microplastic has limited impact on a marine larva. Environ Sci Technol 48:1638-1645

* Kim SW, Kim D, Chae Y, An YJ (2018) Dietary uptake, bio- 
distribution, and depuration of microplastics in the freshwater diving beetle Cybister japonicus: effects on predacious behavior. Environ Pollut 242:839-844

Klein S, Worch E, Knepper TP (2015) Occurrence and spatial distribution of microplastics in river shore sediments of the Rhine-Main area in Germany. Environ Sci Technol 49:6070-6076

Lagarde F, Olivier O, Zanella M, Daniel P, Hiard S, Caruso A (2016) Microplastic interactions with freshwater microalgae: heteroaggregation and changes in plastic density appear strongly dependent on polymer type. Environ Pollut 215:331-339

* Lebreton LCM, van der Zwet J, Damsteeg JW, Slat B, Andrady A, Reisser J (2017) River plastic emissions to the world's oceans. Nat Commun 8:15611

Li HX, Getzinger GJ, Ferguson PL, Orihuela B, Zhu M, Rittschof D (2016) Effects of toxic leachate from commercial plastics on larval survival and settlement of the barnacle Amphibalanus amphitrite. Environ Sci Technol 50: 924-931

Köder MGJ, Kuczera M, Mintenig S, Lorenz C, Gerdts G (2015) Focal plane array detector-based micro-Fouriertransform infrared imaging for the analysis of microplastics in environmental samples. Environ Chem 12:563-581

Malicky H (2005) Ein kommentiertes Verzeichnis der Köcherfliegen (Trichoptera) Europas und des Mediterrangebietes. Linz Biol Beitr 37:533-596

Mathalon A, Hill P (2014) Microplastic fibers in the intertidal ecosystem surrounding Halifax Harbor, Nova Scotia. Mar Pollut Bull 81:69-79

Matsuguma Y, Takada H, Kumata H, Kanke H and others (2017) Microplastics in sediment cores from Asia and Africa as indicators of temporal trends in plastic pollution. Arch Environ Contam Toxicol 73:230-239

* McCormick A, Hoellein TJ, Mason SA, Schluep J, Kelly JJ (2014) Microplastic is an abundant and distinct microbial habitat in an urban river. Environ Sci Technol 48: 11863-11871

McCormick AR, Hoellein TJ, London MG, Hittie J, Scott JW, Kelly JJ (2016) Microplastic in surface waters of urban rivers: concentration, sources, and associated bacterial assemblages. Ecosphere 7:e01556

McNeish RE, Kim LH, Barrett HA, Mason SA, Kelly JJ, Hoellein TJ (2018) Microplastic in riverine fish is connected to species traits. Sci Rep 8:11639

Moore CJ (2008) Synthetic polymers in the marine environment: a rapidly increasing, long-term threat. Environ Res 108:131-139

Moretti GP, Corallini Sorcetti C, Gattaponi P (1981) Trichoptera in the intestinal content of certain fish species. In: Moretti GP (ed) Proc $3^{\text {rd }}$ Int Symp on Trichoptera, Perugia. Series Entomologica, Vol 20. Dr W Junk Publishers, The Hague, p 243-247

Moretti MS, Loyola RD, Becker B, Callisto M (2009) Leaf abundance and phenolic concentrations codetermine the selection of case-building materials by Phylloicus sp. (Trichoptera, Calamoceratidae). Hydrobiologia 630: 199-206

Mouro LD, Zato M, Fernandes ACS, Waichel BL (2016) Larval cases of caddisfly (Insecta: Trichoptera) affinity in Early Permian marine environments of Gondwana. Sci Rep 6:19215

Nel HA, Froneman PW (2018) Presence of microplastics in the tube structure of the reef-building polychaete Gunnarea gaimardi (Quatrefages 1848). Afr J Mar Sci 40:87-89
Nel HA, Dalu T, Wasserman RJ (2018) Sinks and sources: assessing microplastic abundance in river sediment and deposit feeders in an Austral temperate urban river system. Sci Total Environ 612:950-956

* Nuelle MT, Dekiff JH, Remy D, Fries E (2014) A new analytical approach for monitoring microplastics in marine sediments. Environ Pollut 184:161-169

Okano JI, Kikuchi E, Sasaki O, Ohi S (2012) Mineralogical composition of sediment determines the preference for smooth particles by caddisfly larvae during case construction. Ecol Entomol 37:426-434

* Otto C, Svensson BS (1980) The significance of case material selection for the survival of caddis larvae. J Anim Ecol 49: 855-865

Kedondo-Hasselerharm PE, Falahudin D, Peeters ETHM, Koelmans AA (2018) Microplastic effect thresholds for freshwater benthic macroinvertebrates. Environ Sci Technol 52:2278-2286

Khainds M, Davis DR, Price PW (2009) Bionomics of bagworms (Lepidoptera: Psychidae). Annu Rev Entomol 54: 209-226

Kochman CM, Kross SM, Armstrong JB, Bogan MT and others (2015) Scientific evidence supports a ban on microbeads. Environ Sci Technol 49:10759-10761

* Rummel CD, Jahnke A, Gorokhova E, Kühnel D, SchmittJansen M (2017) Impacts of biofilm formation on the fate and potential effects of microplastic in the aquatic environment. Environ Sci Technol Lett 4:258-267

* Schulte U, Spänhoff B, Meyer EI (2003) Ingestion and utilization of wood by the larvae of two Trichoptera species, Lasiocephala basalis (Lepidostomatidae) and Lype phaeopa (Psychomyiidae). Arch Hydrobiol 158:169-183

* Sheath RG, Müller KM, Larson DJ, Cole KM (1995) Incorporation of freshwater Rhodophyta into the cases of caddisflies (Trichoptera) from North America. J Phycol 31:889-896

Skuja A (2010) Diel, seasonal and spatial drift pattern of the caddisfly (Trichoptera) larvae in two medium-sized lowland streams in Latvia. Latv Entomol 49:14-27

Song YK, Hong SH, Jang M, Han GM, Rani M, Lee J, Shim WJ (2015) A comparison of microscopic and spectroscopic identification methods for analysis of microplastics in environmental samples. Mar Pollut Bull 93:202-209

* Stewart RJ, Wang CS (2010) Adaptation of caddisfly larval silks to aquatic habitats by phosphorylation of H-fibroin serines. Biomacromolecules 11:969-974

* Su L, Xue Y, Li L, Yang D, Kolandhasamy P, Li D, Shi H (2016) Microplastics in Taihu Lake, China. Environ Pollut 216:711-719

* Su L, Cai H, Kolandhasamy P, Wu C, Rochman CM, Shi H (2018) Using the Asian clam as an indicator of microplastic pollution in freshwater ecosystems. Environ Pollut 234:347-355

Suter GW, Cormier SM (2015) Why care about aquatic insects: uses, benefits, and services. Integr Environ Assess Manag 11:188-194

* Tanaka K, Takada H (2016) Microplastic fragments and microbeads in digestive tracts of planktivorous fish from urban coastal waters. Sci Rep 6:34351

* Tibbetts J, Krause S, Lynch I, Sambrook Smith GH (2018) Abundance, distribution, and drivers of microplastic contamination in urban river environments. Water 10:1597

Verdonschot PFM, Hering D, Murphy J, Jähnig SC and others (2010) Climate change and the hydrology and morphology of freshwater ecosystems. In: Kernan M, Battarbee RW, Moss BR (eds) Climate change impacts on 
freshwater ecosystems. Wiley, Chichester, p 65-83

Wallace ID, Wallace B, Philipson GN (1990) Keys to the casebearing caddis larvae of Britain and Ireland. Scientific Publication Vol 51. Freshwater Biological Association, Ambleside

Waringer JA (1987) Spatial distribution of Trichoptera larvae in the sediments of an Austrian mountain brook. Freshw Biol 18:469-482

Waringer J, Graf W (2011) Atlas of Central European Trichoptera larvae. Erik Mauch Verlag, Dinkelscherben

Weber A, Scherer C, Brennholt N, Reifferscheid G, Wagner $M$ (2018) PET microplastics do not negatively affect the survival, development, metabolism and feeding activity of the freshwater invertebrate Gammarus pulex. Environ Pollut 234:181-189

Weigand H, Weiss M, Cai H, Li Y, Yu L, Zhang C, Leese F
(2017) Deciphering the origin of mito-nuclear discordance in two sibling caddisfly species. Mol Ecol 26:5705-5715

*Williams DD, Tavares AF, Bryant E (1987) Respiratory device or camouflage? A case for the caddisfly. Oikos 50:42-52

Windsor FM, Tilley RM, Tyler CR, Ormerod SJ (2019) Microplastic ingestion by riverine macroinvertebrates. Sci Total Environ 646:68-74

Wright SL, Thompson RC, Galloway TS (2013) The physical impacts of microplastics on marine organisms: a review. Environ Pollut 178:483-492

Zamora Muñoz C, Svensson BW (1996) Survival of caddis larvae in relation to their case material in a group of temporary and permanent pools. Freshw Biol 36:23-31

Z Zhang K, Su J, Xiong X, Wu X, Wu C, Liu J (2016) Microplastic pollution of lakeshore sediments from remote lakes in Tibet plateau, China. Environ Pollut 219:450-455

Appendix. Examples of microplastics, $\mu$ FTIR spectra, and a picture of the analyzed caddisfly species.

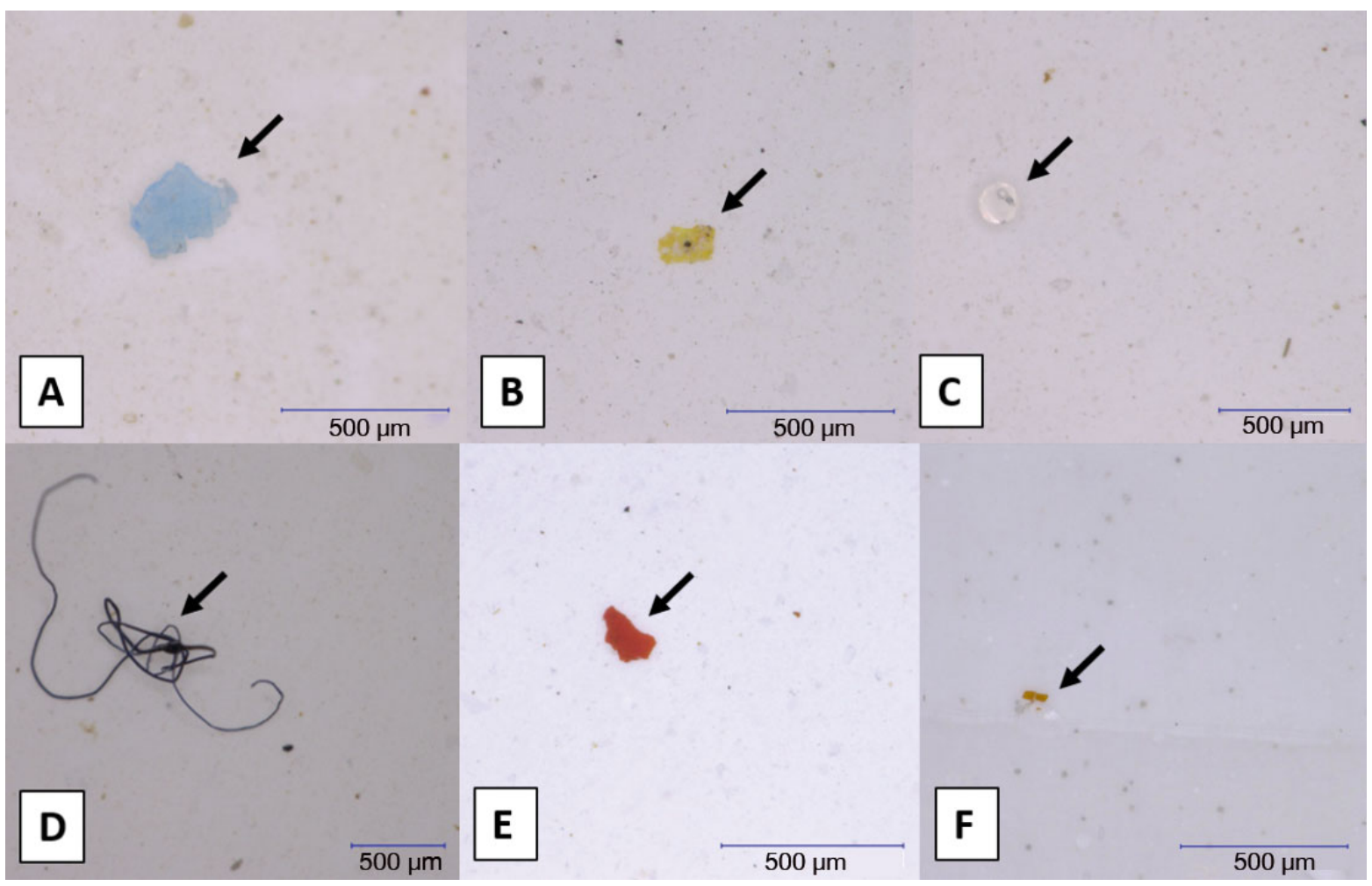

Fig. A1. Examples of microplastics found in Lepidostoma basale cases. (A) Blue polypropylene (PP) fragment, (B) yellow acrylonitrile-butadiene-styrene (ABS) film, (C) transparent polyethylene (PE) sphere, (D) black PP fiber, (E) red thermoplastic polyurethane (TPU) film, (F) orange PP film 

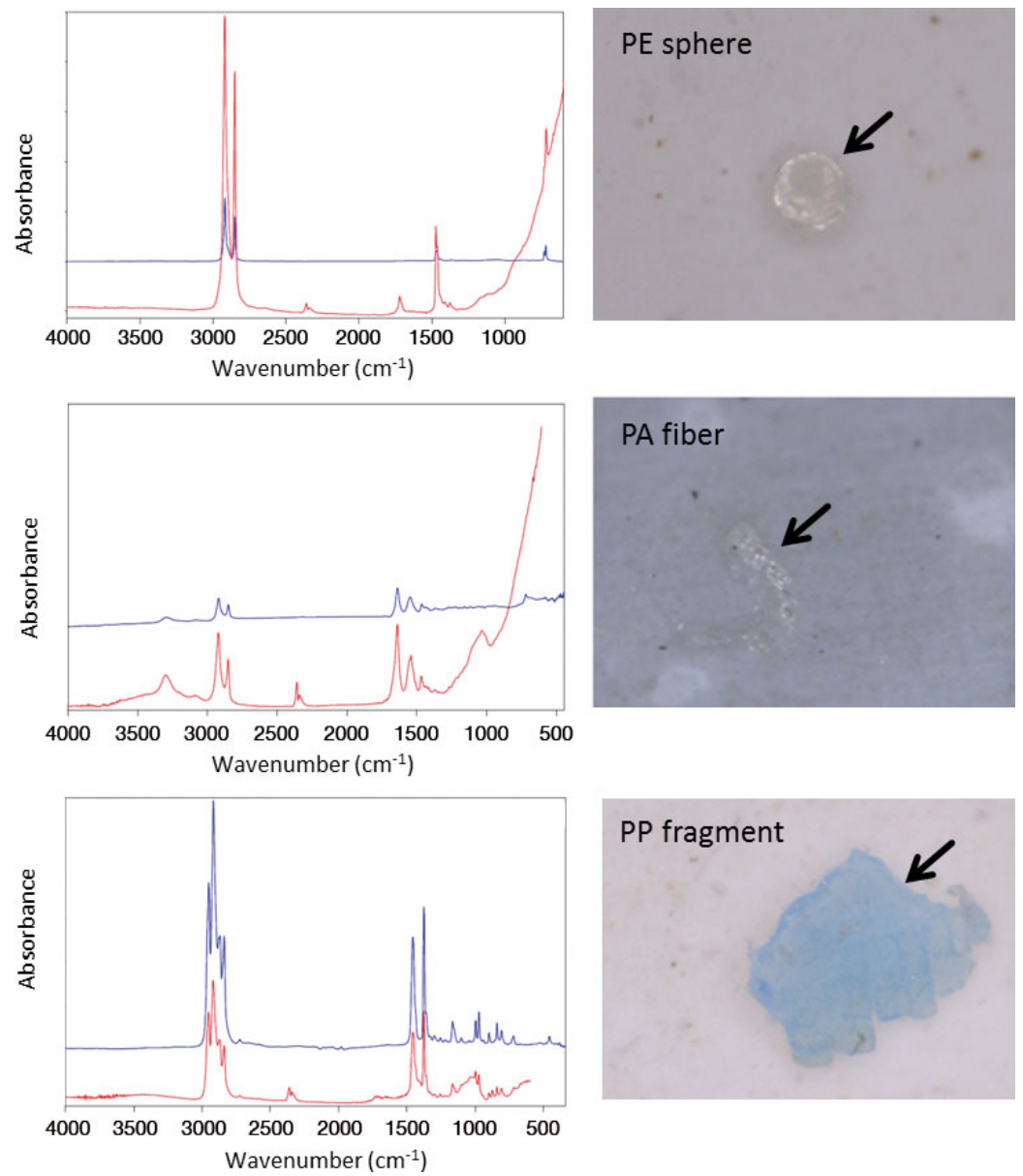

Fig. A2. Spectra of microplastics (red spectra) measured with micro-Fouriertransform infrared spectroscopy ( $\mu$ FTIR) in attenuated total reflectance $(\mu \mathrm{ATR})$ mode. The blue spectra are reference spectra from the Bruker spectra database.

PE: polyethylene; PA: polyamide; PP: polypropylene

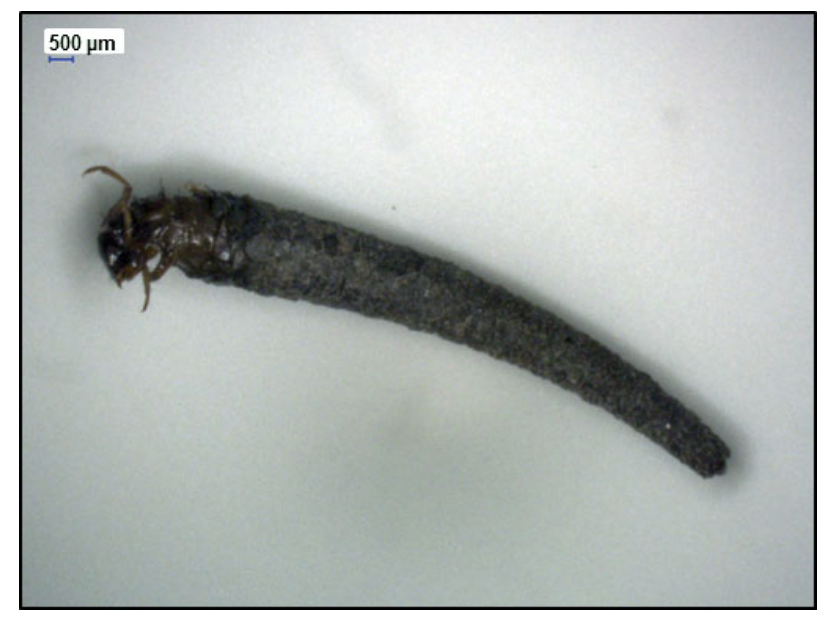

Fig. A3. Case-bearing Lepidostoma basale larva that had microplastics fixed in its case which are not visible to the naked eye

Editorial responsibility: Victor Benno Meyer-Rochow, Oulu, Finland
Submitted: January 24, 2019; Accepted: April 18, 2019 Proofs received from author(s): July 6, 2019 